\title{
Right of Access to Supreme Courts in Light of the Guarantees under Article 6 $\S 1$ of the Convention on Human Rights and Fundamental Freedoms (civil aspect)
}

Nikolina Katić, Matea Bašić, Morana Briški

\section{ABSTRACT}

Right of access to a court, enshrined in Article $6 \oint 1$ of the European Convention on Human Rights and Fundamental Freedoms forms one of the basis for reinforcement of the principle of rule of law. However, the right of access to a court may be limited by provisions of national legislation regulating the functioning of the judicial system and rules of judicial procedure. The higher the hierarchy of the court, the more limits may be placed on the right of access to it. The aim of this article is to examine the different modalities of organisation of supreme judiciaries in European countries (members of the Council of Europe) and mechanisms established in national legislation for filtering applications to those jurisdictions in civil cases, in light of the principles set forth in that regard by the ever evolving case-law of the European Court of Human Rights, and the effects of its judgments and decisions on national legal systems.

\section{KEY WORDS}

European Convention on Human Rights and Fundamental Freedoms; European Court of Human Rights; right of access to a court; Supreme Court; restrictions 


\section{Introduction}

Rule of law and proper administration of justice are some of the fundamental principles of democratic societies and a cornerstone of European democracies. As the President of the European Court of Human Rights (hereinafter: the European Court), The Honourable Judge Guido Raimondi said while opening the 2017 judicial year "[ $t$ ] he rule of law is what sets Europe apart: it is one of the achievements of our civilisation, a rampart against tyranny. This is what Europe represents: a part of the world where the rules of the democratic game have been laid down, and where compliance with these rules is guaranteed by the Constitutional and Supreme Courts"'.

Indeed, national Supreme Courts play a crucial role in the protection of human rights guaranteed by the Convention for the Protection of Human Rights and Fundamental Freedoms (hereinafter: the Convention on Human Rights) within the legal systems of each Member State of the Council of Europe.

In order to be able to benefit from the guarantees of rule of law protected by the Supreme Courts with regard to particular judicial proceedings concerning their rights and obligations, individuals first and foremost need to be able to exercise their right of access to those courts. Without the possibility of bringing their cases before Supreme Courts, the guarantees of rule of law vested in those highest national judicial authorities remain tenuous.

\section{Scope of and limitations to right of access to appellate and cassation courts}

Right of access to a court (particularly right of access to courts of higher instances), as guaranteed under Article $6 \S 1$ of the Convention on Human

Raimondi, G., 2017. Solemn hearing for the opening of the Judicial Year, Opening address of the European Court of Human Rights President Guido Raimondi. Available at http://www.echr.coe.int/Documents/Speech_20170127_ Raimondi_JY_ENG.pdf [accessed 1 August 2017] 
Rights, is, however, not without its limitations.

Article 6 of the Convention on Human Rights does not compel the contracting states to set up courts of appeal or of cassation. The formation of the national judicial system naturally infers on the states a certain margin of appreciation, allowing them to organise their systems in a manner they see fit. Nevertheless, a State, which does set up courts of appeal or courts of cassation is required to ensure the respect for fundamental guarantees contained in Article 6 to all those who appear before them².

\section{Different models of Supreme Court jurisdictions in member states of the Council of Europe}

The states' margin of appreciation in organising their judicial systems with particular regard to the highest levels of jurisdiction is particularly evident through the existence of different models set up within the Council of Europe member states. In substance, there are three different models: the cassation model, the revision model and the appeal model, whilst each Supreme Court also has its share of national particularities ${ }^{3}$. (Lemmens: 2007)

\section{a. Cassation model}

Supreme Courts belonging to the first model, the cassation model, deal exclusively with issues of law, not with the facts. "They do not decide afresh the case that comes before them. They can either reject an appeal or quash the decision of the lower court and remit the case for a fresh examination" (Lemmens: 2007). The Supreme Court is not the court of third or in some cases even fourth instance, so the presentation of parties' own points of view and opinions on the subject matter of the case are not allowed in the cassation model. Supreme Courts of the cassation model do not adjudicate in cases, but rather exercise control over courts of general jurisdiction and examine whether their judgments

2 Delcourt v. Belgium, ECHR 1970, Series A, No. 11, p. 14. Available at: http://hudoc.echr.coe.int/eng? $i=001-57467$ [accessed 17 June 2017]

3 Lemmens, P., 2008. "Guidance by Supreme Courts to Lower Courts on the Requirements of the European Convention on Human Rights". Proceedings of the Regional Conference: The role of Supreme Courts in the domestic implementation of the European Convention on Human Rights, 20 - 21 September 2007 Belgrade. Council of Europe, August 2008:3652. Available at: https://www.coe.int/t/dghl/standardsetting/cddh/Proceedings/Belgrade_PROCEEDINGS\&COVER. pdf [accessed 7 May 2017] 
infringe provisions of national legislation. It may thus be said that Supreme Courts belonging to the cassation model act as a link between the courts of general jurisdiction providing them with coherent guidelines on how to apply the law5. (Zembrzuski: 2014).

\section{b. Revision model}

Courts of revision, like those of the cassation model, do not deal with facts, but only with matters related to breaches of the law. However, they will render their decisions on merits only if it is possible for them to do so without having to gather new facts. But, if a decision on merits of the case requires additional findings of facts, the Supreme Courts of revision model shall remit the case for a retrial or fresh examination to the competent court.

\section{c. Appellate model}

Unlike the previous, Supreme Courts of the appellate model may, in fact, entertain both questions of fact and those concerning the law. The appellate court in this case has the same type of jurisdiction as the (lower) court, which brought the first instance decision. In this model, the appellate court's judgement replaces the judgement of the lower court, so there is no possibility of retrial or afresh proceedings before any other court ${ }^{6}$.

Whatever the model, one of the main features that distinguishes the Supreme Courts from lower (ordinary) courts is the fact that Supreme Courts are on the top of the judicial hierarchy. They are therefore expected to "clarify the law, assure its uniform application and adapt the national case-law to ever-changing circumstances"7.

Precisely because of their special role in the national legal systems, the Supreme Courts play a dual role in domestic legal orders, exercising their public and private purpose ${ }^{8}$. (Jolowitz: 1997) A private purpose could be

5 Zembrzuski, T., 2014. "Access to the Supreme Court - Polish approach". Colloquium of the procedural law The functions of the Supreme Court - issues of process and administration of justice, 11 - 13 June 2014 Warsaw. University of Warsaw, Faculty of Law and Administration 2014. Available at: http://colloquium2014.uw.edu.pl/wp-content/uploads/ sites/21/2014/01/ZEMBRZUSKI_-Access-to-the-Supreme-Court_-Polish.pdf [accessed 1 June 2017]

6 Ibid

7 See mutatis mutandis Lemmens 2008, cited supra.

8 Jolowicz, J.A., 1997. The role of the Supreme Court at the national level a General Report. In Yessiou-Faltsi P., ed. The Role of the Supreme Courts at the National and International Level, Athens: Sakkoulas Publications. 
defined as "achieving, to the maximum possible extent, the application of justice according to law to the parties to the litigation before the court". On the other hand, their public purpose is perceived as wider-reaching, through the reviews of the legality of the lower courts' decisions and the fact that, the lower courts are ordinarily bound by the precedents and stances established by the Supreme Courts. Moreover, the possibility of quashing lower instances' judgements, which demonstrate clear and evident violations of the law is, yet another, significant public task exercised by the Supreme Courts.

Many Supreme Courts of the Council of Europe member states position themselves as serving more of a public than a private purpose ${ }^{10}$. (Norkus: 2015) This is clearly reflected through the existence of various filters imposed with regard to the possibility to appeal to the Supreme Courts in those countries. In this context, the supreme jurisdictions protect individuals far more by providing clear guidance in form of uniform and predictable case-law on specific matters, than if they were to feign review of every application. The regulation of access to the Supreme Court through various filtering mechanisms is ipso facto the result of a compromise between the colliding public and private interests, where, on the one hand, the necessary balance needs to be achieved between parties' right to a fair trial and the exercise of the principle of the rule of law in their individual case and, on the other hand, the public interest of avoiding unnecessary engagement of the highest national judicial authority.

\section{Limitations of access to the Supreme Courts (filtering mechanisms and models)}

The European Court has, on many occasions, held that, "[t] he right of access to the court... is not absolute; it is subject to limitations permitted by implication, in particular where the conditions of admissibility of an appeal are concerned, since by its very nature it calls for regulation by the State, which enjoys a certain margin of appreciation in this regard"11.

9 Ibid.

10 Norkus, R.., 2015. The Filtering of Appeals to the Supreme Courts. Network of the presidents of the Supreme judicial Courts of the EU. Available at http://network-presidents.eu/ [accessed 15 June 2017]

11 Egić v. Croatia, no. 32806/09, ECHR 2014. Available at: http://hudoc.echr.coe.int/eng?i=001-144363 [accessed 17 June 2017]: $§ 48$ 
Limitations of right of access to Supreme Courts have their practical expression in the form of filtering mechanisms and procedures to be followed in order for a case to be eligible for examination at this, highest level of national jurisdiction.

Filtering mechanisms, models and procedure vary from one country to another. They generally depend on the functioning model of the Supreme Court and its legal position in the national judicial order (in particular with regard to whether a Constitutional Court has also been set up in the country).

For example, a Supreme Court cassation model functions in Lithuania and, as a general rule, cassation appeal is not allowed against judgements and rulings of the first instance courts, if they had not been reviewed by the courts of the appellate instance ${ }^{12}$. Conversely, in the United Kingdom, Ireland and Norway, Poland, Denmark and Sweden a leapfrog appeal is available. However, in these jurisdictions, right to appeal the judgement of the court of first instance directly to the Supreme Court is granted only in exceptional situations.

The latter model of filtering appeals before the Supreme Court is called the leave-to-appeal system. As mentioned above, the UK, Ireland, Norway, Denmark and Sweden are prime examples of this type of filtration. In these jurisdictions, a principle of pre-selection or selection "at the door" of the appeals to the Supreme Court is applied. The selection of cases to be adjudicated before these Supreme Courts is done on the basis of quite abstract criteria, emphasizing public purposes of the Supreme Court. Specifically, when a decision in a particular case concerns a matter of general importance or the interests of justice, it is necessary for the case to be heard before the Supreme Court. If not so, as a general rule, no substantive reasoning for the decision to refuse leave to appeal is provided.

The power to select the cases to be heard before the Supreme Court is usually vested in the Supreme Court itself (such as Denmark). It is very important to note that countries, which have this kind of filtering of appeals to the Supreme Courts usually do not have separate Constitutional Courts in their jurisdictions.

12 Ibid Norkus: 2015: 9 
The second model of filtration of the appeals to the Supreme Court includes no judicial filtration stricto sensu. This type of filtration exists in France, Belgium, the Netherlands, Estonia, Spain, Greece and Italy. In these countries, the cassation appeal may be brought before the Supreme Court only by a special lawyer assigned to the Supreme Court or one who fulfils certain prescribed requirements of experience. It is, in principle, mandatory for practising lawyers to advise their clients on the possible outcomes and thus act as a type of filter for unfounded appeals to the Supreme Court'in.

The third model may be described as a mixed one. It possesses some of the features of both models, occasionally shifting more either to the leave to appeal or to no judicial filtration system. This model is, for example, present in Lithuania.

\section{Jurisdiction model and filtering mechanisms of the Supreme Court of the Republic of Croatia}

Government in the Republic of Croatia is based on the trias politica principle of separation of powers into legislative, executive and judicial branches. Judicial power is exercised by the courts. The judiciary is autonomous and independent. The courts administer justice according to the Constitution, international agreements and treaties, which have been signed and ratified and therefore form an integral part of the domestic legal system, laws and other valid sources of law.

The administration of justice in the Republic of Croatia is carried out by courts, including the misdemeanour courts, municipal courts, commercial courts, administrative courts, county courts, the High Misdemeanour Court, the High Administrative Court, the High Commercial Court and, of course, the Supreme Court, as the highest court.

The role of the Supreme Court is to assure the protection of the rule of law and all the rights and freedoms guaranteed by the Constitution. One of its most important roles, inter alia, is ensuring the uniform application of laws and equal treatment of all citizens before the law. Furthermore, the

13 Ibid Norkus: 2015: 11. 
Supreme Court of the Republic of Croatia discusses current issues related to court practice, decides on admissibility and merits of the regular or extraordinary legal remedies in accordance with provisions of national law and decides upon jurisdictional disputes between lower Croatian courts. The Supreme Court also performs other tasks as prescribed by law ${ }^{14}$.

The Supreme Court performs its function of the guardian of the rule of law (ensuring uniform application of laws and equality of all citizens) mainly through its decisions on appeals. Its decisions in specific cases influence the practice and decision making of the lower courts ${ }^{15}$.

The achievement of goals set before the Supreme Court and the role it performs in the Croatian legal system is directly connected to the regime of legal remedies, which afford access to the Supreme Court. It is precisely because of its special role and position within the Croatian legal system hierarchy, that not all cases and appeals may be examined before the Supreme Court on merits. The qualities of realisation of the goals set before the Supreme Court are intrinsic to the possibility of access to the Supreme Court by parties. The Supreme Court would be equally prevented from performing its functions if the parties had no possibility of access to the Supreme Court, but also if such possibility was too broad based. In both of these situations the result would be similar - failure and impossibility of the Supreme Court to fulfil its constitutional assignment - to harmonize the domestic courts' practice and thus influence the consequent development of the domestic law.

Similar to the previously described filtering methods and procedures existent before other European Supreme Courts, the possibility of access to the Croatian Supreme Court is also subject to restrictions. In civil cases, the Supreme Court normally decides upon appeal on points of law (ordinary or "extraordinary"), which has to be filed after the second instance court has brought its (final) decision. Other elements of admissibility are defined through provisions of national civil procedural law imposing specific restrictions on the right of access.

14 Law on Courts. 6.03.2013. NN 28/13, 33/15, 82/15, 82/16. Zagreb: Narodne novine. Available at: https://www.nn.hr/ [accessed 5 June 2017]

15 Crnić, I. "Presentation of the President of the Supreme Court of the Republic of Croatia Ivica Crnic at the demonstration of the new system of publishing case-law of the Supreme Court of the Republic of Croatia", Supreme Court of the Republic of Croatia, 2003. Available at http://www.vsrh.hr/EasyWeb.asp?pcpid=439 [accessed 12 June 2017] 


\section{Limitations of right of access to courts of supreme jurisdiction in the case-law of the European Court}

As previously mentioned, the European Court has clearly stated that right of access to a court as protected under Article $6 \S 1$ of the European Convention is not absolute. Accordingly, limitations in place for such access are not per se incompatible with the Convention.

However, these limitations must not be of such nature to "restrict or reduce a person's access in such a way or to such an extent that the very essence of the right is impaired"16 (Guérin v. France 1998); specifically, such limitations will only be compatible with Article $6 \S 1$ if they pursue a legitimate aim and there is a proportionality between the measures that are being used and the aim that is being sought by those measures.

As often repeated throughout its case-law, the task of the European Court is not to take the place of the domestic courts in the interpretation of national legislation, but rather to verify whether the effects of such interpretation are in line with the European Convention. This is particularly pertinent to the interpretation of procedural rules, for instance those regulating the time-limits for the filing of documents or lodging of legal remedies ${ }^{17}$.

While considering whether the limitations of access to the supreme judicial authority are compatible with Article 6 of the Convention, one should begin those reflections with the European Court's acknowledgment that the very essence of the role of the Supreme Court is "to deal only with matters of the requisite significance" 18 .

The compatibility of the limitations envisaged by the national law with

16 Guérin v. France, no. 25201/94, ECHR 1998. Available at: http://hudoc.echr.coe.int/eng? i=001-58204 [accessed 21 July 2017]

17 See Trevisanato v. Italy, no. 32610/07, ECHR 2016. Available at: http://hudoc.echr.coe.int/eng? i=001-166837 [accessed 17 June 2017]; Miragall Escolano and others v. Spain, nos. 38366/97, 38688/97 40777/98, 40843/98, 41015/98, 41400/98, 41446/98, 41484/98, 41487/98 and 41509/98. ECHR 2000. Avaliable http://hudoc.echr.coe.int/eng?i=001-58451 [accessed 15 June 2017]

18 Dobrić v. Serbia, nos. 2611/07 and 15276/07. ECHR 2011. Available at: http://hudoc.echr.coe.int/eng? i=001-105234 [accessed 17 June 2017]: §45 
the Article 6 of the Convention depends on the particularities of the proceedings in question, and the role of the supreme judicial authority in the national legal order. Nevertheless, the European Court has emphasised that the conditions for the admissibility of the appeal on points of law may be stricter than the ones for an ordinary appeal ${ }^{19}$. Provisions which regulate the procedure and time limits for lodging an appeal ensure the proper administration of justice. They also serve as guarantors of the principle of legal certainty, therefore, as the European Court pointed out: "Litigants should expect those rules to be applied"20.

In case Trevisanato v. Italy the Court considered whether the conditions for the admissibility of the appeal to the Italian Court of Cassation represent the limitation of access to the court, which is contrary to Article 6 of the Convention. Namely, relevant provisions of the Italian Code of Civil Procedure prescribe that the petitioner must explicitly state the legal principle, which has allegedly been breached. Since the applicant in the Trevisanato case failed to formulate such legal principle, his appeal was dismissed. The Court of Cassation asserted that the lack of appropriate wording as to the point of law at issue, precluded it from identifying the substance of appeal and its reasoning. The applicant argued before the European Court that the decision of the Court of Cassation was excessively formalistic, as the legal issue in question could have been identified from the wording of the appeal.

The European Court established that the legitimate aim of provisions governing the admissibility conditions is to maintain legal certainty, as well as proper administration of justice. It further concluded that this limitation was proportionate, as it did not place an excessive burden on the applicant, who could have simply formulated the legal point in question, enabling the Court of Cassation to respond to it by setting up "regula iuris", which could be applied in similar issues. Thus, given the specific role of the Court of Cassation in (internal) Italian legal order, the European Court had found that dismissal of the applicant's appeal on points of law was not overly formalistic in the context of Article 6 of the Convention.

\footnotetext{
19 See Trevisanto v. Italy: 2016: §34, Khalfaoui v. France, no 34791/97, ECHR 1999. Available at: http://hudoc.echr.coe.int/ eng? $i=001-58374$ [accessed 21 July 2017]: $§ 37$

20 See Trevisanato v. Italy, 2016: §32 and Miragall Escolano and others v. Spain, 2000: $\S 33$
} 
Unlike the Trevisanato case, where the European Court established that the impugned rule on admissibility was explicitly articulated in the national law and was not the judge-made rule, in Beles and others v. the Czech Republic ${ }^{21}$ it found, inter alia, the violation of the right of access to a court because the Supreme Court had the discretionary power of granting the leave to appeal on points of law. Such decision was based solely on the opinion of the Supreme Court on whether the disputed decision raised issues of crucial legal importance. This prevented the applicants and their lawyers from assessing their prospects of obtaining leave from the Supreme Court. In the event of leave to appeal on points of law being refused, there was a risk that the applicants' constitutional appeal would have been dismissed as being lodged out of time. The European Court concluded that requiring the applicants to lodge appeals with both the Supreme Court and the Constitutional Court on the same grounds would have created legal uncertainty, which had not facilitated proper administration of justice, as it prevented litigants from using an available remedy.

In the case Miragall Escolano and Others v. Spain, the Court deemed that access to the Supreme Court had been denied based on an unreasonable construction of a procedural requirement, which prevented a claim for compensation from being examined on its merits. In this case, the applicants lodged an administrative complaint to the Supreme Court, which was dismissed because it had been lodged outside the time-limit, namely, after the expiry of one year since the delivery of the impugned decision. However, the applicants were not parties in the proceedings in which the decision was taken, and, furthermore, were unaware of it until it was published in the Official Gazette, although the decision itself did concern their interests. The European Court has emphasized that the applicants "must be able to avail themselves of the possibility to lodge an appeal from the moment they can effectively apprise themselves of court decisions imposing a burden on them or which may infringe their legitimate rights or interests"22. Otherwise, the courts could substantially reduce the time for lodging an appeal or even render any appeal impossible by delaying service of their decisions. On such basis, the European Court concluded that domestic courts' particularly strict interpretation of a procedural rule, deprived the applicants of the right of access to a court.

21 Beles v. the Czech Republic, no. 47273/99. ECHR 2002. Available at: http://hudoc.echr.coe.int/eng? $\mathrm{i}=001-60750$ [acessed 8 June 2017]

22 Miragall Escolano and others v. Spain, 2000: §37 
The issue of deadlines for filing applications to the supreme judicial authority has also been considered by the Court in the case of Tence v. Slovenia ${ }^{23}$, but with regard to the practical aspect of using means other than personal or postal submission of the appeal on points of law. The applicant submitted her appeal on points of law on the last day of the prescribed deadline using a fax machine, whilst the original document was submitted by regular post the following day. Relying exclusively on the fact that the original document containing the appeal on points of law had been submitted after the expiry of the time limit, and disregarding the fax transmission altogether (finding that the applicant was unable to prove the content of the document sent by fax), the Supreme Court dismissed the appeal as lodged out of time. The Supreme Court also emphasised that any faults in the transmission of a document sent by fax, even if attributable to the court, had to be borne by the party submitting such a document. However, the latter conclusion of the Supreme Court had been based on the case-law developed after the applicant had already filed her appeal on points of law by fax, which is why at the time of filing her appeal by fax there was no basis for her to consider that what was recorded as a successful and timely fax transmission, could nonetheless result in the rejection of the appeal as out of time. The European Court thus concluded that the Supreme Court's interpretation of procedural rules in the given circumstances was overly rigid, imposing a disproportionate burden on the applicant, which ultimately led to her inability of accessing the Supreme Court.

In certain cases it is not the interpretation of domestic procedural rules governing access to supreme jurisdiction that infringes the individuals' right of access to a court, but rather the legislation itself, which does not lend itself to any interpretation.

The case of Clionov v. the Republic of Moldova ${ }^{24}$ relates to the issue of payment of court fees in proceedings before the Supreme Court. In accordance with the national procedural provisions valid at the relevant time, appeals on points of law before the Supreme Court could not be

23 Tence v. Slovenia, no. 37242/14, ECHR 2016. Available at: http://hudoc.echr.coe.int/eng? i=001-163352 [accessed 17 June 2017] 
subject to any exemption from court fees, regardless of the appellant's financial situation. This general prohibition of waiving court fees was essentially contrary to the right of access to a court, as guaranteed under Article $6 \S 1$ of the European Convention.

In a number of cases concerning access to supreme jurisdictions, the European Court has also dealt with the issues of the rationae valoris criteria applied in many European legal systems as one of the filters for accessing supreme jurisdictions. In that regard, the European Court has held that setting the financial threshold for appeals to the Supreme Court is not contrary to Convention per se, as it pursues a legitimate aim of preventing overload of the Supreme Court with cases of lesser importance ${ }^{25}$. However, the issue of whether the interpretation of the rationae valoris rule, in light of the circumstances of a particular case infringed the right of access to the supreme jurisdiction, remains to be examined on a case-by-case basis.

Recent judgment of the European Court in the case of Zubac v. Croatia ${ }^{26}$ concerns the lack of access to a court due to a combination of two factors: a mistake made by lower instance courts and, subsequently, an exceedingly formalistic interpretation of procedural rules governing the rationae valoris principle by the Supreme Court. In particular, under relevant Croatian legislation the plaintiff is obliged to indicate the value of his claim in his action. Should he fail to do so, or should the first instance court find that the value stated in the action is clearly incorrect (set either too high or too (ow), it shall verify the value of the claim at the early stages of the proceedings, before examination of the merits. In his initial action, the applicant's predecessor indicated the value of his claim lower than the rationae valoris threshold for filing the appeal on points of law. Subsequently, during the first instance proceedings on merits, he raised the initially indicated value over the prescribed rationae valoris threshold, even though he was not permitted to do so under national legislation. Accordingly, the Supreme Court declared his appeal on points of law inadmissible as not meeting the rationae valoris criteria.

25 Bulfacht v. Croatia, no. 53261/08, ECHR 2011. Available at: http://hudoc.echr.coe.int/eng? ?=001-105215 [accessed 16 June 2017]

26 Zubac v. Croatia, no. 40160/12, ECHR 2016. Available at: http://hudoc.echr.coe.int/eng?i=001-167114 [accessed 30 June 2017] 
However, the European Court held that the particular circumstances of the case (specifically the fact that the lower courts had calculated costs and expenses of proceedings using the raised value of the claim) lead to the conclusion that the interpretation of procedural rules by the Supreme Court had been overly rigid, in a manner, which imposed on the applicant an excessive individual burden of mistakes made by the lower courts and prevented his access to the Supreme Court.

It is interesting to note that the European Court held that existence of longterm case-law of the Supreme Court with regard to the rationae valoris principle, consistent with the Supreme Court's conclusion on inadmissibility of the applicant's appeal on points of law, was of no relevance. This was so because, in the European Court's view, the inadmissibility of the appeal on points of law was essentially caused by the errors made by lower courts, which contrary to domestic law, acted as if the change in the value of the claim at the later stage of the proceedings was, in fact, allowed and accepted. On that basis, the European Court concluded that the Supreme Court's interpretation (or rather the ignoring of the lower court's mistakes) was, "contrary to the general principle of procedural fairness inherent in Article $6 \S 1$ of the Convention" (Zubac 2017:§ 40).

It is further worth noting that the Chamber adopted the Zubac judgment by four votes to three. In a joint dissenting opinion, honourable judges Lemmens, Grițo and Ravarani found there was no reason to hold that conclusions of the Supreme Court had been contrary to the Convention. In particular, the Supreme Court could not be bound by the (implicit) determination of lower courts with regard to the value of the claim, but rather relied on specific provisions of domestic law and its own longstanding case-law in dismissing the appeal on points of law in this particular case. Dissenting opinion especially critiques the notion of "general procedural fairness inherent in Article $6 \S 1$ ", which was introduced by the majority. Finding this new notion unclear, the minority questioned its connection to the right of access to a court as the only right at issue in this particular case.

Moreover, the minority questioned the majority conclusion that the case concerned mistakes made by national courts, since the initial mistake was in fact made by the applicant's predecessor who indicated a higher 
value of the claim at the stage of the proceedings at which such action was not allowed. Even though the lower courts did not declare such action unlawful, this could not have created a reasonable expectation of the applicant's predecessor that his appeal on points of law would have been admissible.

As the Croatian Government's request for referral of the Zubac case to the Grand Chamber of the European Court was accepted, it remains to be seen what the final outcome of the case will be.

At this point, the content of the European Court's case-law regarding the issue of access to the supreme jurisdictions shows that the examination of such cases has more to do with individual circumstances of each case (which are naturally of factual nature) than with any general notion, be it the right to a fair trial or "general procedural fairness inherent in Article 6 $\S 1 "$, as stated in Zubac 27 .

\section{Effect of the European Court's judgments on removing obstacles for access to supreme jurisdictions}

Judgments of the European Court have an effect on national legal systems of member states, which greatly surpasses their seemingly declaratory character (and the usual payment of just satisfaction to the applicants in respective cases). In particular, Article $46 \S 1$ of the European Convention obliges member states to comply with the European Court's judgments, which relate to them. This is done primarily through the implementation of measures of general character, aimed at eliminating the causes of the violations found, and thus, preventing the possibility of future similar violations of individual rights.

Accordingly, violations of the right of access to supreme jurisdictions found in judgments of the European Court have warranted certain 
changes, either in the legislation governing the filtering of appeals to these jurisdictions or in the interpretation of these rules by the national courts of the Member State to which a particular judgment refers.

Generally speaking, the scope of measures that may be applied by the states in order to remove underlying causes of the violation of access to supreme jurisdictions is limited to, either legislative changes (when the violation was caused by the content of provisions of relevant domestic laws) or, more frequently, measures that can and should affect the necessary changes in the case-law of domestic courts examining the admissibility of applications lodged to Supreme Courts.

For example, following the findings of the European Court in Clionov v. the Republic of Moldova (merits described above), in order to prevent similar violations of the Convention in the future, Moldovan authorities have amended relevant legislation so that it now provides for the possibility to request exemption from court fees or the deferral of their payment. Under the amended legislation, in case the appellant requests exemption or deferral of payment of court fees, the appeal on the points of law shall not be dismissed and the panel of three judges shall decide whether to grant the request ${ }^{28}$. Thus, the European Court's judgment has led to the removal of restriction of access to the Supreme Court, which was contrary to the European Convention.

A similar situation also occurred, with regard to the European Court's judgment in the case of Miragall Escolano v. Spain (also analysed above). In the process of execution of the said judgment, the Spanish authorities amended relevant legislation setting clear guidelines for the identification of the first day of the time-limit allowed for lodging appeals ${ }^{29}$. These amendments had led to closure of the examination of the case by the Committee of Ministers, and were clearly an effective method of prevention of similar violations, as there have been no other similar pending cases against Spain before the European Court.

Markedly different, in Tence v. Slovenia, the Government of the

28 Status of execution of judgment in Clionov v. the Republic of Moldova. Available at: http://hudoc.exec.coe.int/ eng? $\mathrm{i}=004-6798$ [accessed 21 July 2017]

29 Final resolution of the Committee of Ministers in Miragall Escolano and others v. Spain no. ResDH(2001)158: 2001 Available at: http://hudoc.exec.coe.int/eng?i=001-56011 [accessed 21 July 2017] 
Respondent State deemed sufficient to undertake awareness raising measures, as acquainting of domestic courts' with the conclusions expressed in the judgment of the European Court shall, in their view, be sufficiently effective for preventing similar violations of the Convention in the future ${ }^{30}$. Such a stance remains to be assessed by the Committee of Ministers with regard to its effectiveness in prevention of similar violations of the European Convention in the future.

\section{Conclusion}

Right of access to a court, guaranteed under Article $6 \S 1$ of the European Convention, though generally encompassing all levels of national jurisdiction, nonetheless shows some restrictions do apply.

However, such restrictions must not impair the very essence of the right of access to a court. In particular, the Court held that, in order to remain compatible with Article 6 of the Convention, restrictions of the right of access to a court must necessarily pursue a legitimate aim, and the means employed (the limitations placed on the right of access) must be proportionate to the aim pursued. This general rule is applicable to all levels of national jurisdiction, including highest judicial authorities (Supreme or Cassation Courts).

It will be interesting to see how the European Court's case-law will further develop on the issue, particularly in the case Zubac v. Croatia, which is currently pending before the Grand Chamber, which is expected to provide specific guidelines as to the application of the rationae valoris criteria in access to highest national courts. 


\section{B Bibliography}

Action Report of Slovenia in the case of Tence v. Slovenia. 2017. Available at: https://rm.coe.int/168070c4e9 [accessed 31 July 2017]

Beles v. the Czech Republic, no. 47273/99. ECHR 2002. Available at: http:// hudoc.echr.coe.int/eng? $i=001-60750$ [acessed 8 June 2017]

Bulfacht v. Croatia, application no. 53261/08, ECHR 2011. Available at: http://hudoc.echr.coe.int/eng? $\mathrm{i}=001-105215$ [accessed 16 June 2017]

Clionov v. the Republic of Moldova, no. 13229/04, ECHR 2007. Available at: http://hudoc.echr.coe.int/eng? i=001-82595 [accessed 17 June 2017]

Crnić, I. "Presentation of the President of the Supreme Court of the Republic of Croatia Ivica Crnić at the demonstration of the new system of publishing case-law of the Supreme Court of the Republic of Croatia", Supreme Court of the Republic of Croatia, 2003. [online]. Available at: http://www.vsrh.hr/EasyWeb.asp?pcpid=439 [accessed 12 June 2017]

Delcourt v. Belgium, no. 2689/65. ECHR 1970, Series A no. 11, p. 14. Available at: http://hudoc.echr.coe.int/eng?i=001-57467 [accessed 17 June 2017]

Dobrić v. Serbia, no. 2611/07 and 15276/07, ECHR 2011. Available at:

http://hudoc.echr.coe.int/eng? $\mathrm{i}=001-105234$ [accessed 17 June 2017]

Egić v. Croatia, no. 32806/09, ECHR 2014. Available at: http://hudoc.echr. coe.int/eng? i=001-144363 [accessed 17 June 2017]

Final resolution of the Committee of Ministers in Miragall Escolano and others v. Spain no. ResDH(2001)158: 2001. Available at: http:// hudoc.exec.coe.int/eng?i=001-56011 [accessed 21 July 2017]

Guérin v. France, no. 25201/94, ECHR 1998. Available at: http://hudoc. echr.coe.int/eng? $i=001-58204$ [accessed 21 July 2017]

HUDOC-EXEC 2017. Department for the excution of judgments of the 
ECHR. Available at: http://hudoc.exec.coe.int/eng\#\{"EXECDocu mentTypeCollection":["CEC"]\} [accessed 21 July 2017]

Jolowicz, J. A., 1997. The role of the Supreme Court at the national level a General Report. In Yessiou-Faltsi P., ed. The Role of the Supreme Courts at the National and International Level, Athens: Sakkoulas Publications.

Khalfaoui v. France, no 34791/97, ECHR 1999. Available at: http://hudoc. echr.coe.int/eng? $i=001-58374$ [accessed 21 July 2017]

Lemmens, P., 2008. "Guidance by Supreme Courts to Lower Courts on the Requirements of the European Convention on Human Rights". Proceedings of the Regional Conference: The role of Supreme Courts in the domestic implementation of the European Convention on Human Rights, 20 - 21 September 2007 Belgrade. Council of Europe, August 2008:36-52. Available at: https://www. coe.int/t/dghl/standardsetting/cddh/Proceedings/Belgrade_ PROCEEDINGS\&COVER.pdf [accessed 7 May 2017]

Law on Courts 6.03.2013. NN 28/13, 33/15, 82/15, 82/16. Zagreb: Narodne novine. Available at: https://www.nn.hr/ [accessed 5 June 2017]

Miragall Escolano and others v. Spain, nos. 38366/97, 38688/97, 40777/98, 40843/98, 41015/98, 41400/98, 41446/98, 41484/98, 41487/98 and 41509/98, ECHR 2000 Available at: http://hudoc.echr.coe.int/ eng? $\mathrm{i}=001-58451$ [accessed on 5 June 2017]

Norkus, R., 2015. The Filtering of Appeals to the Supreme Courts. Network of the presidents of the Supreme judicial Courts of the EU. Available at http://network-presidents.eu/ [accessed 15 June 2017]

Raimondi, G., 2017. Solemn hearing for the opening of the Judicial Year, Opening address of the European Court of Human Rights President Guido Raimondi. Available at http://www.echr.coe.int/ Documents/Speech_20170127_Raimondi_JY_ENG.pdf [accessed 1 August 2017]

Tence v. Slovenia, application no. 37242/14, ECHR 2016. Available at: http://hudoc.echr.coe.int/eng?i=001-163352 [accessed 17 June 2017] 
(T) Trevisanato v. Italy, no. 32610/07, ECHR 2016. Available at: http://hudoc. echr.coe.int/eng\#\{"itemid":["001-166688"]\} [accessed 15 June 2017]

Zembrzuski, T., 2014. "Access to the Supreme Court - Polish approach". Colloquium of the procedural law: The functions of the Supreme Court - issues of process and administration of justice, $11-13$ June 2014 Warsaw. University of Warsaw, Faculty of Law and Administration 2014. Available at: http://colloquium2014.uw.edu. pl/wp-content/uploads/sites/21/2014/01/ZEMBRZUSKI_-Access-tothe-Supreme-Court_-Polish.pdf [accessed 1 June 2017]

Zubac v. Croatia, no. 40160/12, ECHR 2016. Available at: http://hudoc. echr.coe.int/eng?i=001-167114 [accessed 30 June 2017] 
Nikolina Katić (nina_katic@hotmail.com) holds a Law Degree from the University of Zagreb. She also holds a Legal English Certificate from Cambridge University. She is an Assistant Agent of the Republic of Croatia before the European Court of Human Rights and the Head of the Litigation Department. She has extensive experience in representation before the European Court of Human Rights, with focus on cases relating to war crimes and human rights violations in the criminal field. She works as a legal expert on international human rights standards on multiple projects in Croatia and in the region. She regularly gives lectures on the implementation of the Convention on Human Rights as well as the case-law of the European Court of Human Rights in the Croatian legal system for judges, prosecutors and civil servants.

Matea Bašić (mateabasic13@gmail.com) holds a Law Degree from the University of Zagreb. She has been a fully qualified lawyer in Croatia since 2006. During her work within the judiciary, she has gained extensive insight and practical knowledge on the national legal system and case-law of domestic courts. Currently, she is an Assistant Agent of the Republic of Croatia before the European Court of Human Rights and the Head of Department for the Execution of Judgments of the European Court of Human Rights. Her area of specialty is the case-law of the European Court of Human Rights and its effects on the national legal systems of Council of Europe member states. As an expert on human rights standards, she maintains ongoing involvement in training activities on the case-law of the European Court of Human Rights and the implementation of its judgments at the national level.

Morana Briški (moranabriski@gmail.com) holds degrees in Law and European Studies from the University of Zagreb and I'Université Paris II - Panthéon Assas respectively. She is currently an Assistant Agent of the Republic of Croatia 
(2) before the European Court of Human Rights and the Head of Department for case-law research at the Office of the Government Agent of the Republic of Croatia before the European Court of Human Rights. She specializes in case-law research and analysis in the field of international human rights. She is a certified HELP trainer and a member of the EJTN's Human Rights and Fundamental Freedoms Sub-Working Group. 